\title{
Thomas Edison (1847-1931) \\ Biography with special reference to X-rays
}

\author{
Richard F. Mould
}

This article is a brief biography of the American inventor Thomas Alva Edison (1847-1931) with special reference to his involvement with X-rays. His work involved the invention of the phonograph, the design of an electric power plant, an electric railway, the incandescent light bulb, a fluoroscope, and motion pictures. Selected quotations attributed to Edison complete this biography of this remarkable inventor who took out a total of 1,093 American patents.

\section{NOWOTWORY J Oncol 2016; 66, 6: 499-507}

Key words: Thomas Edison, X-rays, family genealogy, phonograph, carbon microphone, Menlo Park, incandescent lamps, electric power distribution, electric railway, motion pictures, Clarence Dally, X-ray lamp, neuroradiology, first X-ray photograph in USA, Roentgen mania, fluoroscope, World War I

\section{Introduction}

Thomas Alva Edison (1847-1931), Figure 1, is one of the greatest inventors who ever lived, and certainly the most prolific. Oncologists and medical physicists will have heard of his work with fluorescent materials, including the design of his fluoroscope, and the death of his laboratory assistant Clarence Dally: the first radiation martyr. Edison took out 1,093 US patents, (and 1,239 overseas patents) including those relating to the phonograph, improvements to the incandescent light bulb and the carbon granule microphone as an improvement for Alexander Graham Bell's telephone. He invented a system for generating and distributing electricity and designed the first power plant and produced the first talking motion pictures. Often called the wizard or genius of Menlo Park for the invention factory he created in New Jersey. Two references [1, 2] have been particularly helpful for providing information on the inventions, other than Edison's work with X-rays, which are contained in this biography.

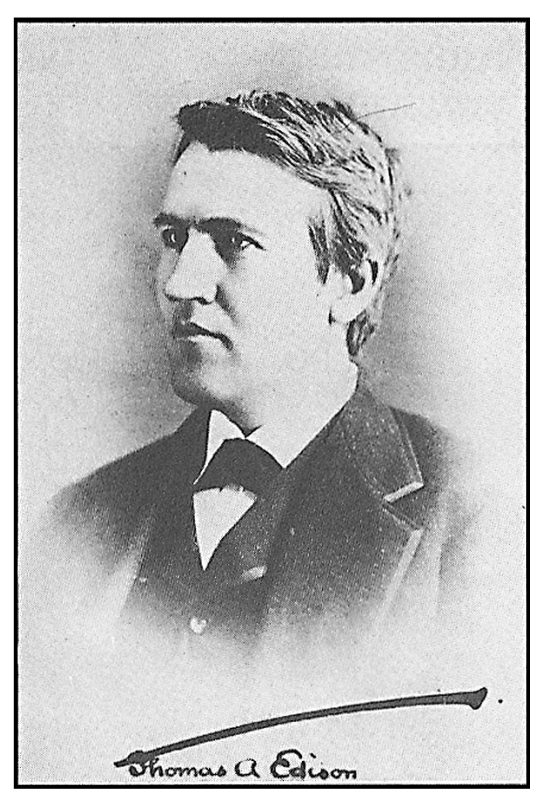

Figure 1. Thomas Alva Edison

Cartmel

Grange over Sands

Cumbria LA11 6QG

United Kingdom 


\section{Early life}

Thomas Alva Edison was born in Milan, Ohio, on 11 February 1847, the seventh and last child of Samuel Ogden Edison Jr., (1804-1896) and Nancy Matthews Elliott (1810-1871) who was born in New York. Samuel Jr., was the son of a Loyalist refugee (Samuel Sr., had fought in the War of 1812 as a Captain in the $1^{\text {st }}$ Middlesex Regiment) who eventually settled in Ontario in a village known from 1811 as Vienna (previously known as Shewsbury). Samuel Jr. was to flee Ontario because he took part on the losing side in the unsuccessful Mackenzie Rebellion of 1837. The family then ended up in Milan, Ohio.

His schooling record was not outstanding and apparently his mind often wandered: his teacher was overheard calling him 'addled'. He only received three months of official schooling and thereafter he was taught at home by his mother.

Edison developed hearing problems at an early age: these have been attributed to scarlet fever and recurring untreated middle-ear infections. However, Edison himself blamed these problems on being hit on the ears by a train conductor when his chemical laboratory in a boxcar caught fire and he was thrown off the train together with his apparatus and chemicals [1-4].

\section{Newspaper salesman}

In 1854 the Edison family moved from Milan to Port Huron, Michigan. This marked Thomas'first entry into'business' when he sold candy and newspapers on trains between Port Huron and Detroit. In addition he also sold vegetables to supplement his income. It was at this time that he studied quantitative analysis and undertook chemical experiments on the train. He obtained the exclusive right to sell newspapers on the road, and with four assistants, he set in type and printed the Grand Trunk Herald, which he sold with his other papers $[3,5]$.

\section{Telegraph operator}

Thomas Edison became a telegraph operator on the Grand Trunk Railway at Stratford Junction, Ontario, after he had saved three-year old Jimmie MacKenzie from being struck by a runaway train. The boy's father was so grateful that he trained Thomas as a telegraph operator.

In 1866 at the age of 19 Thomas Edison moved to Louisville, Kentucky working for the Associated Press bureau news wire as an employee of Western Union. He used his spare time to read and to experiment, but in 1867 this led to disaster and to being fired. He was working with a lead acid battery when he spilled sulphuric acid on the floor and it ran between the floorboards and onto his boss's desk below [6].

Some of Edison's earliest inventions were related to telegraphy with his first patent being for the electric vote recorder: US Patent 90,646 granted on 1 June 1869.

\section{Marriages and children}

On Christmas Day 1871 Edison married 16-year old Mary Stillwell whom he had met two months earlier when she was an employee in one of his shops. They had three children. She died at the early age of 29 years and Edison remarried on 24 February 1886, 20-year old Mina Miller, the daughter of the inventor Lewis Miller. They also had three children.

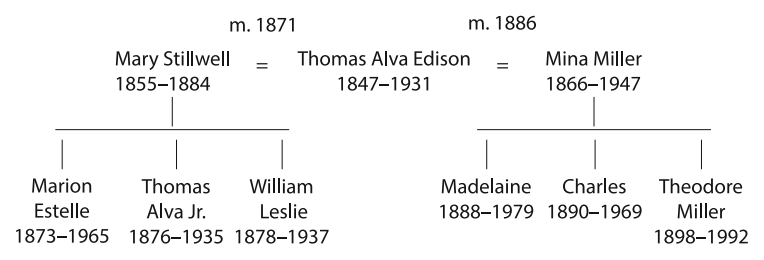

William was a graduate of the Sheffield Scientific School at Yale and became an inventor. Charles was Governor of New Jersey 1941-1944 and took over his father's company and experimental laboratories after Thomas' death in 1931. Theodore qualified in 1923 as a physicist and has more than 80 patents to his name. His eldest son, Thomas Alva Edison Jr., was a failure in that after using his name to advertise quack medicines and dubious inventions, his father asked him to change his name. This he did briefly going by the name of Thomas Willard. He later started a failed mushroom farm. Married twice, his first marriage, in 1899, to a stage actress Marie Louise Toohey, was in a secret ceremony.

\section{Phonograph}

The invention of the phonograph in 1877 ensured that Thomas Edison was given widespread acclaim and became a celebrity, Figure 2 . His first phonograph recorded on tinfoil around a grooved cylinder. It had limited sound quality and recordings could only be played a few times. In April 1878 Edison travelled to Washington D.C.to demonstrate his phonograph before the National Academy of Sciences, congressmen, senators and US President Hayes. The Washington Post described Edison as a 'genius' and his presentation as 'a scene ... that will live in history'. Edison then did little to develop his phonograph until the 1880s when Alexander Graham Bell, Chichester Bell and Charles Tainter produced a phonograph-like device that used wax-coated cardboard cylinders. $[1,2,7,8]$.

\section{The first industrial laboratory: Menlo Park}

It was Thomas Edison who designed and built the world's first industrial laboratory. This was in Menlo Park, in Middlesex County, New Jersey, and was built by Edison with the funds from the sale of his quadruplex telegraph. Within a decade the laboratory had expanded to occupy two city blocks. Today the original Edison Laboratory has been reconstructed at Greenfield Village in Dearborn, Michigan. Edison worked at Menlo Park from 1876. In 1884 after the death of his first wife, Edison moved to Llewellyn Park in West Orange, New Jersey. In 1885 he purchased a property called Seminole Lodge in 


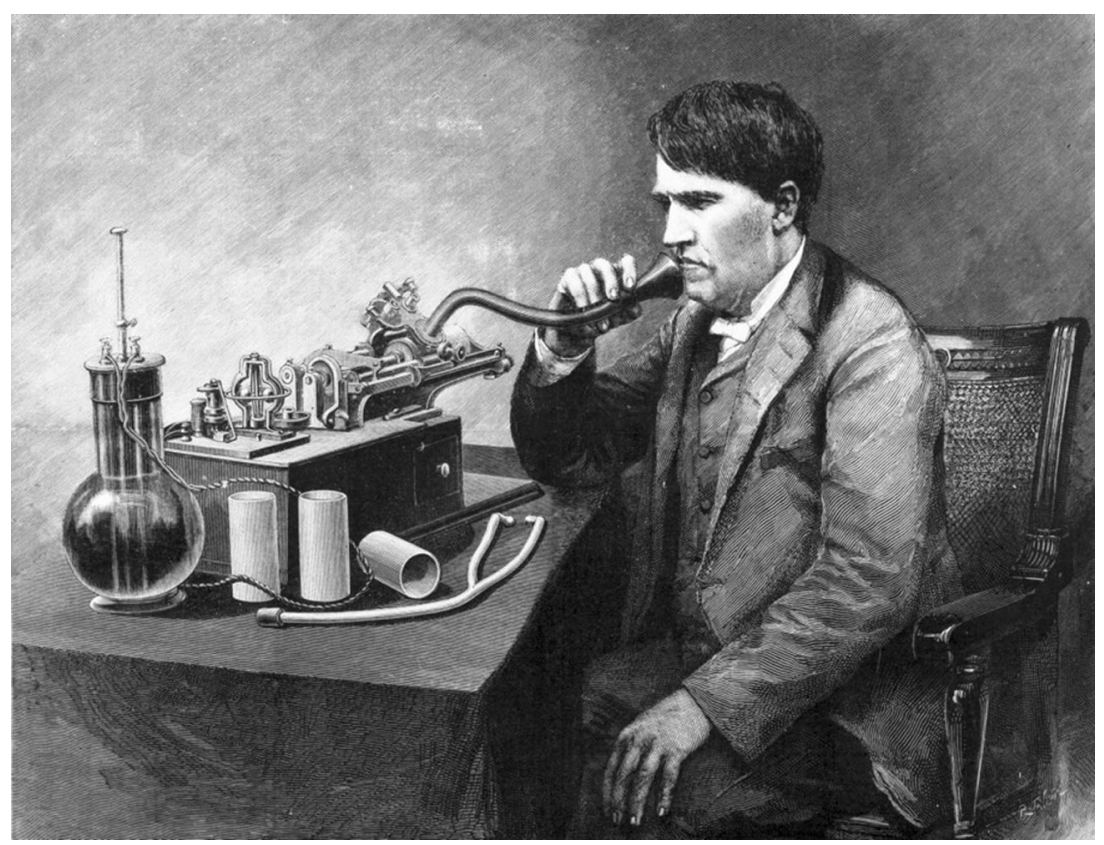

Figure 2. Engraving of Thomas Edison and his phonograph: published in 1881 in the Illustrated London News. (Courtesy: The Science Museum, Science \& Society Picture Library, London)

Fort Myers, Florida, as a winter retreat, where he died on 18 October 1931 from diabetic complications.

\section{Carbon microphone}

The carbon telephone transmitter was invented and developed by Edison in 1877-1878. It was used in all telephones, with the Bell receiver, until the 1980s. It was also used in radio broadcasting and public address systems in the 1920 s. The US patent 222,390 (8 November 1878) was titled 'Carbon telephones'.

\section{Incandescent lamps}

Edison had several patents titled electric lamps or incandescent lamps during the period 1880-1883 with a few also in later years. His aim was to invent a system of electrical illumination that would compete with gas and oil-based lighting. However, he did not invent the incandescent lamp, although this is often claimed in the literature. He was in fact preceded by the English scientist Sir Joseph Swan (1828-1914) who in 1860 produced a red glow in a carbon filament in an air exhausted glass bulb. Other earlier inventors had also devised incandescent lamps, including Alessandro Volta's (1745-1827) demonstration of a glowing wire in 1800 . However, they were commercially impractical incandescent lamps: including that invented by Sir Humphry Davy (1778-1829).

Edison experimented first with carbon filaments and then with platinum and other metals, but finally settled upon the choice of carbon. His first successful test was in 1879 when the lamp lasted 13.5 hours, (later in 1880 with a carbonised bamboo filament the lamp could last over 1,200 hours). His US patent 223,898 (27 January 1880) was for an electric lamp using 'a carbon filament or strip coiled and connected to platina contact wires'. This was the first commercially practical incandescent light $[1,9]$.

\section{Edison Electric Light Company}

The Edison Electric Light Company in New York City was formed in 1878 and the first public demonstration of his incandescent light bulb was at Menlo Park on 31 December 1879. In May 1880 Edison installed his electric light system in the Oregon Railroad \& Navigation Company steamship Columbia. This was the first commercial used of his incandescent light bulb. The first public building to use Edison's lamps was the Mahen Theatre in Brno, (now in the Czech Republic) in 1882.

\section{Electric power distribution}

In 1880 Edison founded the Edison Illuminating Company to commercially distribute an electric utility to compete with the existing gas light companies. In 1889 he patented a system for electric power distribution (US patent 493,858 ) and the first investor-owned electricity utility was established in 1882 in Pearl Street station, New York. This provided 110 volts installed in penny arcades and viewers DC to $59 \mathrm{cu}$ stomers in lower Manhattan. However, a direct current (DC) system was suitable only for the high density of customers found in large cities. This caused commercial problems for Edison as it placed him in direct competition with George Westinghouse (1846-1914) who installed his first alternating 
current (AC) systems in 1886. The Thomson-Houston Electric Company of Lynn, Massachusetts was another competitor with AC-based power stations. The so-called War of the Currents came to an end in 1892 when Edison was forced out of his own company by shareholders dissatisfied with their financial returns and when J.P. Morgan (1837-1914) engineered a merger of Edison General Electric and Thomson-Houston. The new company was called General Electric and was run by the board of Thomson-Houston.

\section{Electric railway}

In 1879 at the Berlin Exhibition, Siemens installed an electric railway about one-third of a mile in length, over which a locomotive hauled a train of three small cars at a speed of about 8 mile per hour, carrying some 20 people each trip. Also in 1879, Edison designed his dynamo and adopted the same form of machine as a motor [10]. The work was funded by Henry Villard (1835-1900) and Edison since the directors of the Edison Electric Light Company refused to invest in such a scheme. It was not a success for Edison although in 1891 he was still being granted patents for an 'electric locomotive' (US patents 475,491-3) and an 'electric railway' (US patent 475,494).

\section{Motion pictures}

Edison obtained a patent in 1891 for a motion picture camera or Kinetograph (US patent 589,168 31 July 1891; reissued in 1902). Edison was responsible for the electromechanical aspects and his employee William Kennedy Dickson (1860-1935) for the photographic and optical development. The Kinetoscope was a peep-hole viewer where viewers could watch short, simple films. They were first exhibited in May 1891.

The Vitascope (the same name was given to Edison's first fluoroscope) was designed by Thomas Armat (1866-1948), in April 1896, manufactured by the Edison factory and marketed in Edison's name. It was used to project motion pictures in public screenings in New York City. In 1913 he exhibited motion pictures with sound track on cylinder recordings, mechanically synchronised with the film, the Kinetophone, Figure 3. However, the system was far from perfect and disappeared in 1915. By 1918 Edison had ceased working on motion pictures.

\section{X-ray experiments 1896}

Thomas Edison is best known for his work on fluoroscopes and the search for an improvement to the fluoroscopic material barium platino-cyanide which was used by Wilhelm Conrad Röntgen (1845-1923) when he discovered X-rays on 8 November 1895.

The first published bibliography on X-rays was compiled in August 1896 was by Edward P. Thompson [11] who was

\section{TALKING PICTURES} A FACT! A REALITY!

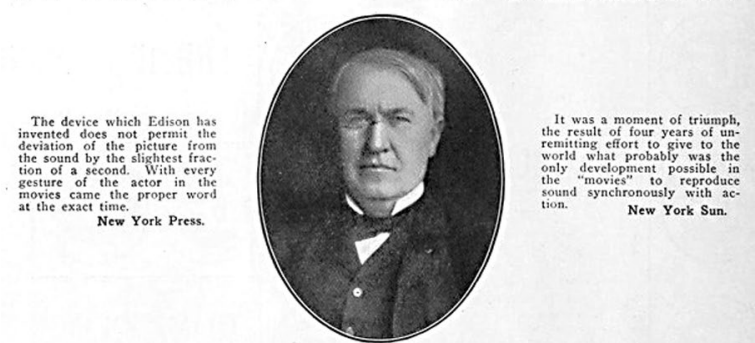

THOS. A. EDISON

STARTLES THE GIVILIZED WORLD AND REVOLUTIONIZES THE PICTURE BUSINESS THE KINETOPHONE ABSOLUTELY THE FIRST PRACTICAL TALKING PICTURE EVER MADE PERFECT SYNCHRONISM AND ILLUSION VOICE AND ACTION TAKEN SIMULTANEOUSLY

ANY FIRST CLASS OPERATOR CAN HANDLE

THE MACHINE CONTROLS THE OPERATOR HOLDING FILM AND RECORD TOGETHER IN PERFECT UNISON. IN FACT HE CAN TURN HIS BACK TO SCREEN AND SYNCHRONIZE TO A FRACTION OF A SECOND
CONTRACTS NOW BEING MADE FOR MACHINES AND SERYICE BEING MADE FOR MACHISES
WRITE FOR PARTICULARS

Figure 3. Advertisement from The Moving Picture News

a Member of the American Institute of Electrical Engineers and of the American Society of Mechanical Engineers. He was also the author of Inventing as a Science and Art. Thompson devoted an entire chapter in his bibliography to Thomas Edison publications, either alone or with co-authors. The full list is given in Table I. Many of the publications by Edison are to be found in the Electrical Engineer (New York). Edison's work with X-rays in 1896 can also be assessed from the commentaries in the British science journal Nature for 1896, see Table II [12].

The Edison references in Table III are taken from the 1896 bibliography of 1044 references given as an Appendix in Röntgen's biography by Otto Glasser, published in 1933 [13]. Obviously not all of Edison's papers are included, only those some 35 years after they were written, which were considered by Otto Glasser to be the most important. The first reference in Table III is for an Abstract only, with authors cited as Edison, Morton, Swinton \& Stanton. The first two are American and the second two are British, and the reference is probably only describes the experience of the authors: see also March 1896 in Table II. All other references in Table III have only Edison as an author. There is only a single reference for November 1896, following those for April 1896. Tables II \& III seem to indicate that Edison ceased experimenting with X-rays by mid- to late 1896 . 
Table I. X-ray experiments by Thomas Edison in 1896 [11]

- Edison's experiments. Characteristics of discharge tube, photographic plates, electrical apparatus, fluorescence, etc.

- Reason why thin walls are better than thick. X-rays and post-phosphorescence

- To prevent puncture of discharge tube by sparks

- Variation of vacuum by discharge and by rest

- External electrodes discharge through higher vacuum than internal

- Deposit on glass from aluminium electrodes

- Possible application of X-rays. Fluoroscent lamp

- Piltchikof's experiment. Greater emission of X-rays by a tube containing an easily fluorescent substance

- Electrodes of silicon carbide (Carborundum)

- Chemical decomposition of the glass bulb detected by the spectroscope

- Sciagraphs. Duration of exposure dependent upon distances

- Difference between X-rays and light illustrated by different photographic plates. Times of exposure

- Size of discharge tube to employ for given apparatus

- Preventing puncture at the phosphorescent spot

- Instruction regarding the electrical apparatus. Electrical dimensions of apparatus

- Salts fluorescent by X-rays. 1800 chemical tested

- X-rays apparently passed around a corner. Theoretical considerations

- Permeability of different substances to X-rays. A list of a variety of materials

- Penetrating power of X-rays increased by reduction of temperature. Tube immersed in oil, and the oil vessel in ice. $X$-rays transmitted through steel 0.25 inch thick

- X-rays not obtainable from other sources than discharge tubes

- Anaesthetic property of X-rays

\section{First X-ray photograph in the USA?}

It cannot be determined who in the USA took the first $X$-ray photograph [14]. Thomas Edison might have been the first, but it could also have been Michael Pupin (1858-1935) of Columbia University who claimed in his biography [15] that he took a 'picture' in January 1896. Whereas the editors of The Rays, a History of Radiology in the United States and Canada [16] give priority to Arthur Williams Wright (1836-1915) of Yale during the first successful X-ray experiment in North America on 27 January 1896 as shown on a page of Wright's laboratory notes.

\section{Neuroradiology}

On 5 February 1896 Edison received a cable from William Randolph Hearst (1863-1951), the renowned publisher of the New York Journal. The cable read as follows. 'Will you as an especial favour to the Journal undertake to make a cathodograph of human brain kindly telegraph at our expense'. Edison accepted the challenge and three days later in the
Table II. X-ray experiments by Thomas Edison in 1896 as described in the journal Nature [12] There are no Edison-entries for the months January and February 1896 or for the months July-December 1896

\section{March 1896}

Edison is experimenting in the direction of taking pictures by snap-shots, and has already succeeded in reducing the time of exposure to 7 seconds, getting clearly defined images of strips of metal after the rays had penetrated a heavy piece of cardboard and a vulcanised plate. Edison reports that his eyes were sore after working for several hours with his fluorescent tubes; but he is not certain that this result is specially attributable to the X-rays. With regard to Mr Edison's experiments, a few seconds are found to be ample for taking pictures of pieces of metal. When it is a question of photographing a portion of the body, however, it is a different matter; but even then with a good tube 30 or 40 seconds will give a very fair result.

\section{April 1896}

Thomas Edison sends a telegram to Lord Kelvin, according to which calcium tungstate, when suitably crystallised, showed fluorescent phenomena under the action of X-rays in a far more marked degree than barium platino-cyanide. A surgeon with this product, good Crookes' tubes, and a large coil could certainly dispense with the tedious process of photography.

\section{June 1896}

By coating the inside of a Crookes' tube with fluorescent crystals, Mr Thomas Edison is stated to have produced an electric lamp in which 'all the energy which is in an incandescent lamp is lost in heat is turned into light. One of the new lamps of only 4 candle-power is said to give light equal to that obtained by the usual 16 candlepower incandescent lamp.

Table III. X-ray experiments by Thomas Edison in 1896 as published in 1933 [13]

\section{March 1896}

Effect of X-rays upon the eye. (Abstract) Nature 53: 421

\section{March 1896}

Experiments with Roentgen rays. Elec Eng (NY) 21: 305

\section{April 1896}

Further experiments in fluorescence under the cathode rays. Elec Eng (NY) 21: 340

\section{April 1896}

Are Roentgen-ray phenomena due to sound waves? Elec Eng (NY) 21: 365

\section{April 1896}

Roentgen-ray lamp and other experiments. Elec Eng (NY) 21: 378

18 November 1896

Recent Roentgen-ray observations. Elec Eng (NY) 22: 520

New York Times it was reported that Edison would attempt that morning 'to demonstrate the penetrating powers of the new light by an experiment in photographing a man's brain'. Instead of using a Crookes' tube he made a tube out of a regular Edison incandescent light bulb. He gave up on 14 February, as reported by the New York Daily Tribune, blaming not only broken tubes and difficulties in obtaining a suitable vacuum, but also the "insuperable obstacles" imposed by the skull itself. 


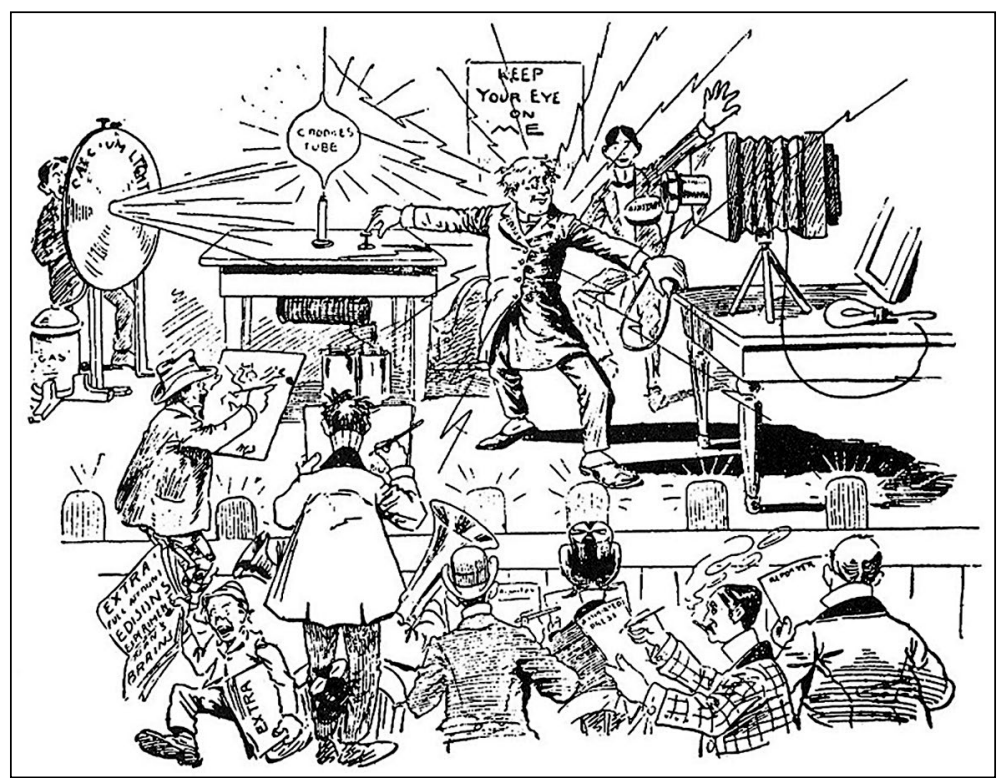

Figure 4. Cartoon of February 1896 in the New York World. On the large circular disc on the left is written 'Calcium Light' and there is a Crookes' tube on a table between the disc and Edison. The newspaper boy's placard, bottom left, refers to the brain experiment

\section{Roentgen mania}

Roentgen mania was a term coined by the press, referring to the general public in the early months of 1896 . However, it was also used to refer to Edison in an issue of the American journal Electrical World in February 1896. 'Edison himself has been having a severe attack of Roentgen mania. The newspapers having reporters in attendance at his laboratory did not suffer for copy, as the yards of sensational matter emanating from this source attest, and we learnt that last week Mr Edison and his staff worked through 70 hours without intermission, a hand organ being employed during the latter hours in keeping the force awake'. Figure 4 is a cartoon which appeared in a February 1896 issue of the New York World.

\section{Edison fluoroscope}

Figure 5 is the first drawing of what was to become known as the Edison Fluoroscope and was first described in the literature on 4 April 1896 [17]. Initially it was called the Vitascope.

\section{National Electric Light Association exposition, New York 1896}

At the May 1896 exposition in New York of the National Electric Light Association, Edison's historic fluoroscope was exhibited and the general public could view'see the bones' of their hands, Figure 6. Dally's duty was to recognise and control as far as possible by manipulation of the output of the induction coil used to excite the Crookes tube, since the functioning of the Crookes tube under prolonged excitation was far from excellent.

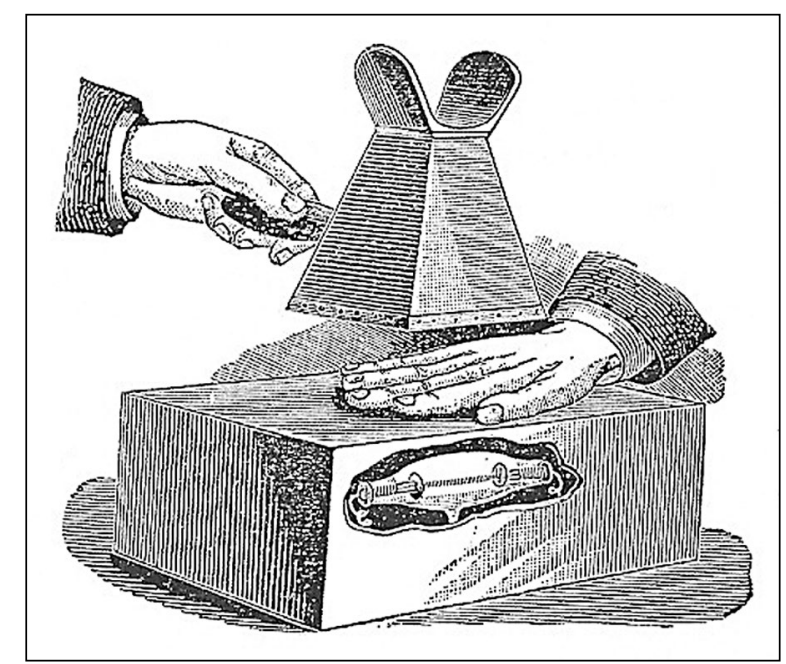

Figure 5. The Edison fluoroscope, April 1896

\section{Edison's new X-ray lamp}

Clarence Dalley (1865-1904) was the first X-ray martyr. His death was caused by $X$-ray exposure working as a glass blower in the laboratory of Thomas Edison on'Edison's New X-Ray Lamp' (Fig. 7) and other X-ray applications. Details of this lamp were originally published in Scientific American and then republished in Trevert's small book on X-rays which was written in 1896 for the general public [18].'It is a highly exhausted oblong glass bulb having wires sealed in the ends, each wire being provided with a small plate inside the bulb. One of these plates is inclined to cause a distribution of the rays over the side of the lamp. The inner surface of the lamp is covered with a granular mineral substance (originally calcium tungstate but later a more efficient fluorescent 


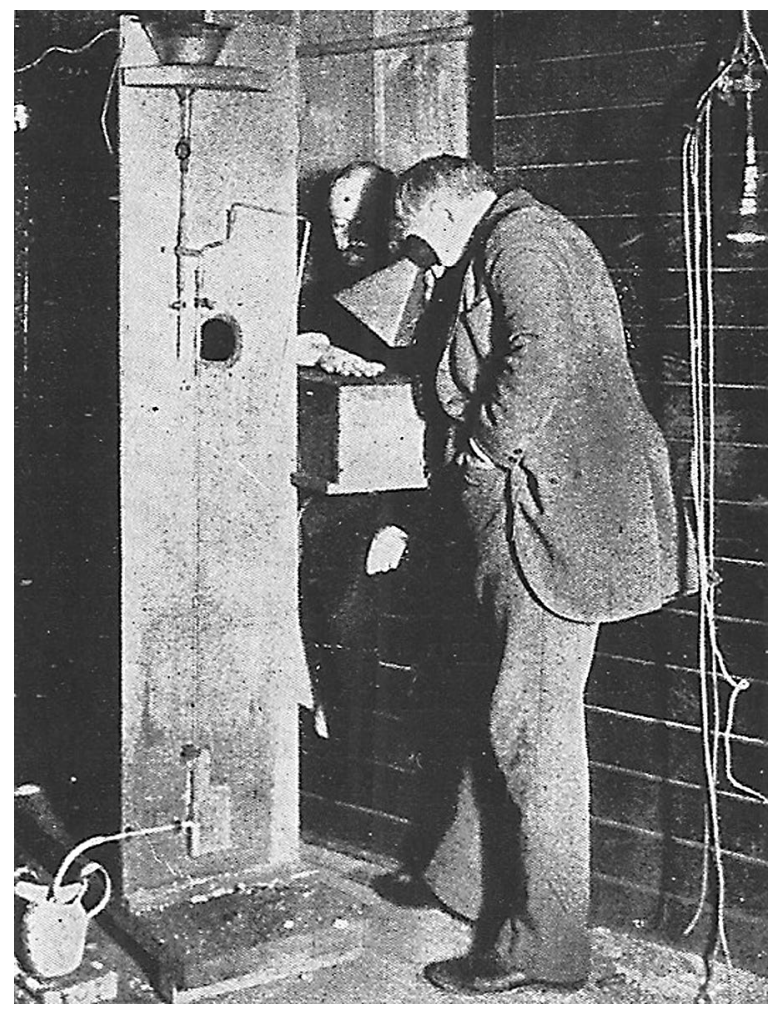

Figure 6. This photograph shows Edison looking through the fluoroscope at the New York Exposition. It is Clarence Dally who is using his hand as a test object but Thompson [11] states it is T. Commerford Martin (who is the author of reference [2])

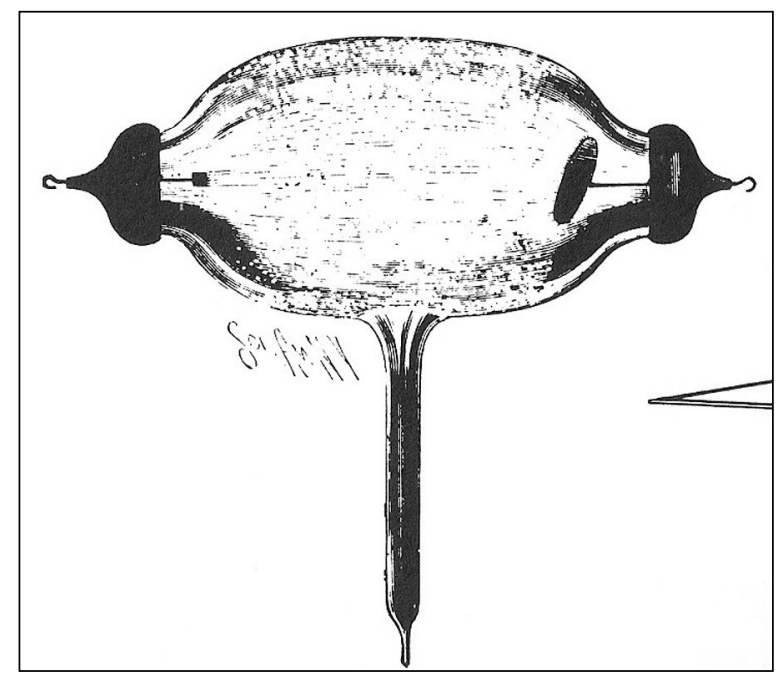

Figure 7. Drawing from Scientific American of Edison's X-ray lamp, 1896

material which was not named) which is fused on the glass and is highly fluorescent. When the lamp is connected to an induction coil the material becomes luminous'.

The results of manufacturing such lamps was disastrous in terms of X-ray hazards and Thomas Edison soon noted that his assistant Clarence Dally suffered from loss of hair and skin ulcers, and abandoned his fluorescent lamp. Dally was the first known American to die from prolonged exposure to X-rays having started experimenting with X-rays early in 1896. His work at the Edison laboratories were primarily on the development of the focus X-ray tube and on finding improved fluorescent materials.

By 1900 Dally had lost his eyebrows and eyelashes as well as all the hair on the front of his scalp and on his hands and fingers. Because the skin on his hands had grown swollen and painful, he constantly switched hands during his work with the X-rays. When in June 1902 the graft failed (144 skin grafts from the leg were applied in total) and cancer was diagnosed in the remaining tissues, the hand was amputated above the wrist. The cancer continued to spread and eventually both arms required simultaneous removal: one at the shoulder joint and the other at the elbow. Dally died from mediastinal recurrent cancer in October 1904 at the early age of 39 years [19-22].

\section{Criticism of Edison}

An editorial in JAMA published just before Clarence Dally's death, jeered at Edison for 'rehashing' facts 'learned by physicians through sad experience seven years ago'. 'He has, as far as can be judged by the newspaper reports, found nothing that has not been found before, and offered no explanation that is of any value.'The JAMA editors in the summer of 1903 thus already believed that the dangers from $\mathrm{X}$-ray exposure were old and uninteresting news.

\section{After X-ray experimenting in 1896}

When Edison ceased experimenting with $X$-rays towards the end of 1896 when he was 49-years old. He had by then completed his major work but he did not retire as seen from the list of patents, Table IV, (Thomas Commerford Martin's book [1] was written in 1910 which is why the patent list ends in 1909). However, he was not as successful as before. Edison was, though, slowing down as seen by the total number of patents for the years 1906-1909, when for example compared with his number of US patents for the 10-year period 1872-1881. That is, 14 in 1906, 12 in 1907, 8 in 1908 and 2 in 1909. For the earlier period 38 in 1872, 25 in 1873, 15 in 1874, 10 in 1875, 12 in 1876, 20 in 1878, 14 in 1879, 60 in 1880, 89 in 1881. Edison's only involvement with X-rays after 1896 was through commercial enterprises selling X-ray tubes, such as the Edison Decorative and Miniature Lamp Department of the General Electric Company, Figure 8.

\section{Ore-Milling \& Portland Cement}

Edison was also interested in ore milling and in cement. In 1881 he had formed the Edison Ore-Milling Company but this was not a success and he did not return to this work till 1889. He hoped that his process could help the most depleted Eastern US mines compete with those in Western 
Table IV. Examples of the subjects of Edison's US patents 1897-1909 [1]

- Phonograph (1897, 1899, 1900, 1903, 1904, 1905, 1909)

- Horns for talking machines (1905)

- Breaking rock (1897)

- Screening pulverised material, bricking pulverised material (1898, $1900,1903)$

- Filament for incandescent lamps: manufacturing (1898)

- Reheating compressed air for industrial purposes (1899)

- Apparatus for screening fine materials, Portland cement clinker (1900)

- Burning Portland cement clinker $(1902,1906)$

- Cement kilns $(1903,1904,1907)$

- Reversible Galvanic battery $(1900,1901,1902,1903)$

- Storage batteries $(1902,1903,1904,1905,1908)$

- Alkaline batteries (1904)

- Sound recording device $(1901,1906)$

- Handling cable drawn cars on inclines (1902)

- Electrical automobile (1902)

- Photographic film for moving picture machine (1903)

- Making articles by electro-plating $(1903,1906)$

- Electrical welding apparatus (1904)

- Automobiles (1908)

- Flying machines (1908)

US. He invested much money into this project but it was unsuccessful, as additional sources of ore were found in the Midwestern US. The Edison Portland Cement Company was founded in 1899 and he promoted the idea that there could be widespread use of cement for the construction of low-cost homes. Surprisingly he also considered the use
Table V. 12 selected quotations which are associated with Thomas Edison

- 'Genius is one percent inspiration and ninety-nine percent perspiration'. [Edison is quoted in Harper's Monthly Magazine of September 1932 as the originator of this quotation]

- 'There is no expedient to which a man will not resort to avoid the real labour of thinking.' [Over his desk in Menlo Park (and at several locations in the factory), Edison displayed this quotation attributed to Sir Joshua Reynolds]

- 'I have not failed, I've just found 10,000 ways that won't work'

- 'Many of life's failures are people who did not realise how close they were to success when they gave up'

- Five percent of the people think; ten percent of the people think they think; and the other eighty-five percent would rather die than think

- 'We often miss opportunity because it's dressed in overalls and looks like work'

- 'When you have exhausted all possibilities, remember this - you haven't'

- 'The three great essentials to achieve anything worthwhile are, first, hard work; second, stick-to-itiveness; third, common sense'

- 'Our greatest weakness lies in giving up. The most certain way to succeed is always to try just one more time'

- 'To invent, you need a good imagination and a pile of junk'

- 'Just because something doesn't do what you planned it to do doesn't mean it is useless'

- 'Negative results are just what I want. They're just as valuable to me as positive results. I can never find the thing that does the job best until I find the ones that don' $\mathrm{t}^{\prime}$

of concrete in the manufacture of phonographs, furniture, refrigerators and pianos. This project failed [23]

\section{World War I}

Edison advised preparation for war, claiming that technology would represent the future of warfare. In 1915 he

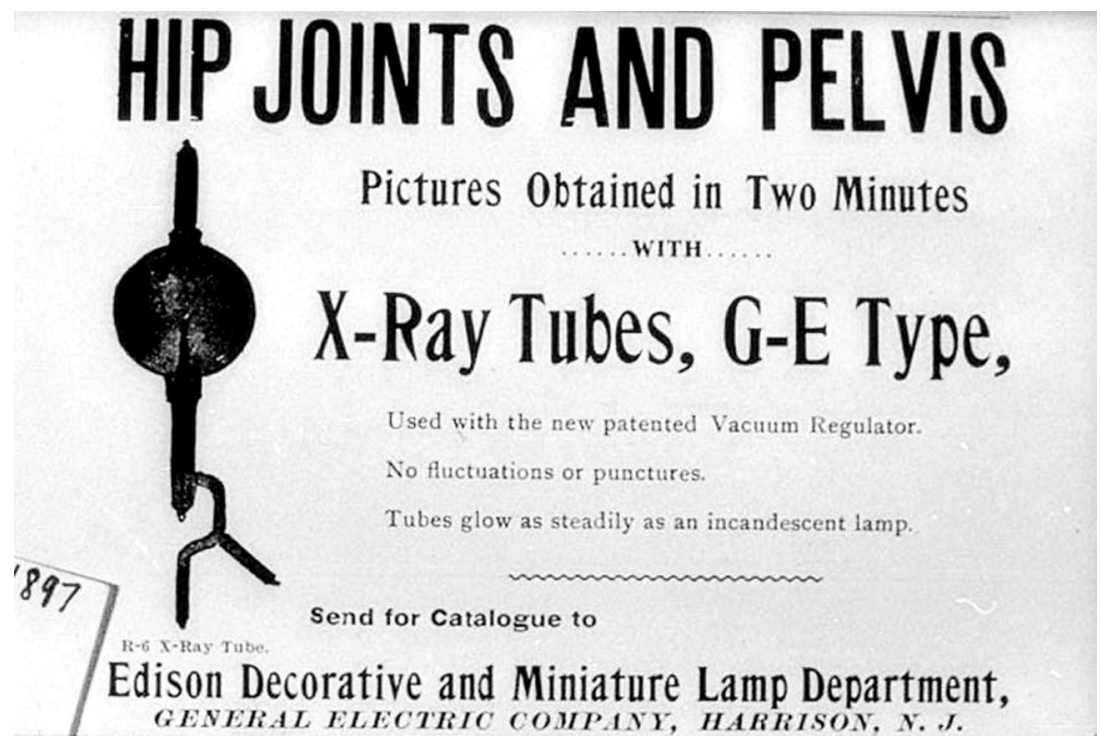

Figure 8. Advertisement of 1897. The three small text lines read as follows. Used with the new patented Vacuum Regulator. No fluctuations or punctures. Tubes glow as steadily as an Incandescent Lamp 

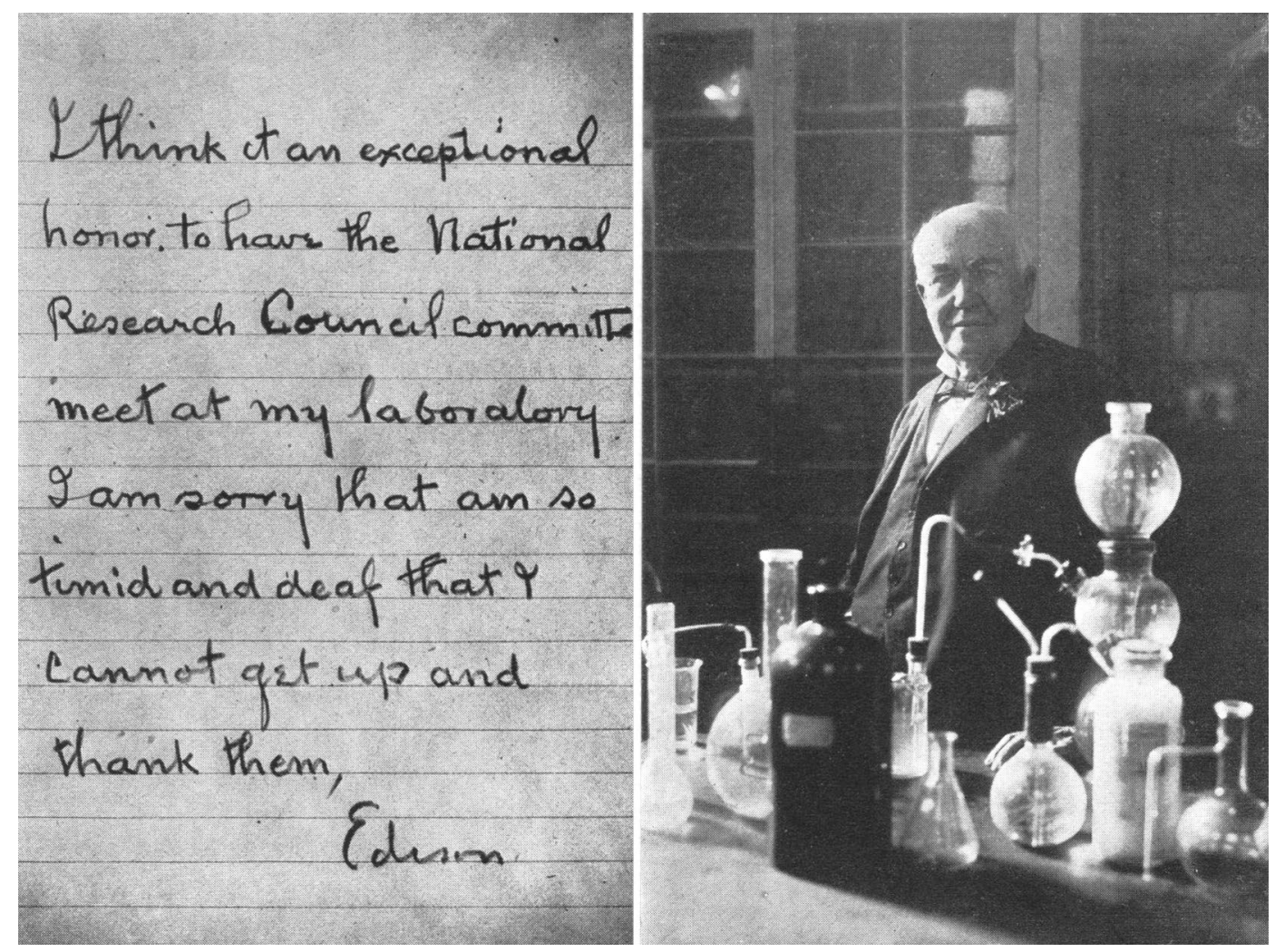

Figure 9. Thomas Edison, 31 October 1924 (Courtesy: The Institution of Engineering \& Technology, London). See text for details

was made the head of the Naval Consulting Board (mainly an advisory Board) which was the US government's attempt to incorporate science into its defense program. During WWI Edison spent most of his time doing naval research, particularly on submarine detection.

\section{Quotations}

See Table V.

\section{Edison in 1924}

This photograph (Fig. 9), taken towards the end of his life, shows Edison in his laboratory greeting the National Research Council Committee on Industrial Lighting at its first meeting, 31 October 1924.

\section{Richard F. Mould MSc, PhD}

4, Town End Meadow

Cartmel Grange-over-Sands

Cumbria LA116QG

United Kingdom

e-mail:manorroadsouthport@yahoo.co.uk

\section{References}

1. 2016 https://en.wikipedia.org/wiki/Thomas_Edison.

2. Martin TC. Thomas Edison His Life and Inventions. First published 1910. Republished by The Perfect Library, printed by Amazon.co.uk, Ltd., 2011.
3. Josephson M. Edison. New York: McGraw Hill, 1959.

4. Baldwin N. Edison: Inventing the Century. Chicago: University of Chicago Press, 2001.

5. Homans JE ed. Thomas Alva Edison. The Cyclopaedia of American Biography. New York: The Press Association Compilers Inc, 1918.

6. Baldwin N. Edison: Inventing the Century. Hyperion, 1995.

7. Washington Post. Genius before science. 19 April 1878.

8. Edison TA. Telephones or speaking-telegraphs. US patent 203,018 filed 13 December 1877, issued 30 April 1878.

9. Howard BR. Intellectual Property Law for Engineers and Scientists. Hoboken: John Wiley \& Sons, 2004.

10. Scientific American 18 October 1879.

11. Thompson EP. Roentgen Rays and Phenomena of the Anode and Cathode. New York: D. Van Nostrand, 1896.

12. Mould RF. Annotated X-ray Bibliography 1896-1945. Warsaw: Polish Oncological Society, 2014.

13. Glasser O. Wilhelm Conrad Röntgen and the Early History of the Roentgen Rays. London: John Bale, Sons \& Danielsson, 1933.

14. Evans WA. American pioneers in radiology. In: Glasser O, ed. The Science of Radiology. London: Baillière, Tindall \& Cox, 1933, pp 22-38.

15. Pupin MI. From Immigrant to Inventor. New York: Scribner \& Sons, 1923.

16. Brecher R, Brecher E. The Rays a History of Radiology in the United States and Canada. Baltimore: Williams \& Wilkins, 1969.

17. Edison TA. The Edison fluoroscope. Electrical World 27: 360, 4 April 1896.

18. Trevert E. Something about X-Rays for Everybody. Lynn: Bubier Publishing, 1898.

19. Edison TA. Edison's new X-ray lamp. Sci Am 1896.

20. Edison TA. Röntgen-ray lamp and other experiments. Elec Eng 15 April 1896; 21: 378, and Nature 4 June 1896; 54: 112.

21. Editorial Comment. Edison and X-ray injuries.JAMA 22 August 1903;41:499.

22. Brown P. Clarence Madison Dally (1865-1904). In: Brown P. American Martyrs to Science through the Roentgen Rays. Springfield: Charles C Thomas, 1936, pp 32-42.

23. Library of Congress. Inventing entertainment: the early motion pictures and sound recordings of the Edison Companies. 2016. https://www.loc. gov/collections/edison-company-motion pictures. 